\title{
2 Synthesis and pharmacological evaluation of novel cis and trans 3 3-substituted anilidopiperidines
} \\ Ivana I. Jevtić ${ }^{\text {· Katarina Savić Vujović }}{ }^{2}$. Dragana Srebro ${ }^{2}$. Sonja Vučković ${ }^{2}$ - Milovan D. Ivanović ${ }^{3}$. \\ Slađana V. Kostić-Rajačić ${ }^{1}$ (i)
}

Received: 20 December 2019 / Revised: 5 June 2020 / Accepted: 23 June 2020

(c) Maj Institute of Pharmacology Polish Academy of Sciences 2020

\begin{abstract}
Background 4-Anilidopiperidine class of synthetic opioid analgesics, with it's representative fentanyl, are by far the most potent and clinically significant for the treatment of the severe chronic and surgical pain. However, side effects of $\mu$-opioids are often quite serious. In order to improve the pharmacological profile of this class of opioid analgesics, a novel fentanyl analogs were designed, synthesized and evaluated in vivo for their antinociceptive activity.

Methods The title compounds were prepared using known synthetic transformations, including $N$-bromoacetamide mediated Hofmann rearrangement, highly selective carbamate cleavage with trimethylsilyl iodide and dehydration of carboxamide group to nitrile in the presence of $\mathrm{SOCl}_{2}$. The antinociceptive activity of the synthesized compounds was determined by tail-immersion and formalin test.

Results The scalable synthetic route towards novel fentanyl analogs bearing nitrogen groups in position $\mathrm{C}_{3}$ of piperidine ring is designed. In addition, Hofmann rearrangement was substantially improved for the more efficient synthesis of previously published 3-substituted fentanyl analogs. The series of ten fentanyl analogs was tested in vivo for their antinociceptive activity. The most potent compound of the series was found to be cis-4, based on the determined $\mathrm{ED}_{50}$ values in tail-immersion test. Conclusion Of ten compounds tested for their antinociceptive activity, compound cis- $\mathbf{4}$ is characterized by high potency, rapid beginning and short duration of action and due to this might be incorporated in different pharmaceutical forms.
\end{abstract}

\section{Keywords Opioid $\cdot$ Fentanyl $\cdot$ Antinociceptive $\cdot$ Anilidopiperidine}

\section{Introduction}

Pain management is one of the major fields of medicine and important goal in public health. While the inflammationrelated pain is usually treated by COX inhibitors (e.g. aspirin, ibuprofen, paracetamol), severe chronic and surgical

Electronic supplementary material The online version of this article (https://doi.org/10.1007/s43440-020-00121-2) contains supplementary material, which is available to authorized users.

Slađana V. Kostić-Rajačić

sladjana.kostic@ihtm.bg.ac.rs

1 ICTM-Department of Chemistry, University of Belgrade, Njegoševa 12, 11000 Belgrade, Serbia

2 Department of Pharmacology, Clinical Pharmacology and Toxicology, Faculty of Medicine, University of Belgrade, 11000 Belgrade, Serbia

3 Faculty of Chemistry, University of Belgrade, Studentski trg 12-16, 11000 Belgrade, Serbia pain is mainly managed by opioid analgesics. Of these, $\mu$-opioid agonists are by far the most potent and clinically significant. Selective $\kappa$ and $\delta$ agonists are much less effective [1]. In addition to pain treatment, opioids are also useful in the conditions such as acute pulmonary edema, cough, diarrhea and shivering [2]. However, side effects of $\mu$-opioids are often quite severe, including acute life-threatening respiratory depression, sedation, constipation, nausea, as well as chronic tolerance and physical dependence. Due to the extensive opioid misuse or abuse, opioid addiction is serious, worldwide health issue [3]. Among several classes of important opioid drugs, fentanyl is a prototype of the 4-anilidopiperidine class of synthetic opioid analgesics [4]. Fentanyl is 80-100 times more potent than morphine, having fast onset and a relatively short duration of analgesia $[5,6]$. Fentanyl congeners in clinical use (alfentanil, sufentanil and remifentanil) are also very potent, short-acting drugs. Fentanyl transdermal patches effectively manage some types of chronic pain, principally terminal cancer pain [7]. Numerous 
fentanyl analogues have been synthesized in the past several decades, both to establish the structure-activity-relationship (SAR) and to find drugs with superior pharmacological profile (potency, selectivity, pharmacokinetics). Two such drugs, carfentanil and thiafentanil become useful veterinary opioids [5, 8, 9].

This study aims at improving our previously published synthetic procedure $[10,11]$ and to examine the antinociceptive activity of some new fentanyl analogues. The tests involved models of phasic (tail-immersion) and tonic (formalin test) pain in rats. Relationship between the structure of new compounds and the experimentally determined antinociceptive activity (potency and the duration of action) is briefly discussed.

\section{Material and methods}

\section{General procedure for the synthesis of compounds 2 and 4}

To a magnetically stirred solution of carboxamide $(0.9 \mathrm{mmol}$, 1.0 equiv.) in $\mathrm{MeOH}(3 \mathrm{~mL}), \mathrm{LiOH} \cdot \mathrm{H}_{2} \mathrm{O}$ (14.0 equiv) and NBA (4.0 equiv.) were added. Mixture was allowed to steer at $60^{\circ} \mathrm{C}$, in dark. Reaction was monitored by TLC, on $\mathrm{SiO}_{2}$ plates, using mixture of $n$-hexane/EtOAc $=1: 1$ and $\mathrm{CH}_{2} \mathrm{Cl}_{2} / \mathrm{MeOH}=9: 1$, as eluent. After $5 \mathrm{~min}$, mixture was concentrated by rotary evaporator to give a residue which was mixed with $1 \mathrm{M}$ solution of $\mathrm{NaOH}$. The mixture was extracted with $2 \times 25 \mathrm{~mL}$ of $\mathrm{CH}_{2} \mathrm{Cl}_{2}$. Organic layers were combined and concentrated by rotary evaporator. Obtained crude product was purified by dry flash chromatography.

\section{Procedure for the synthesis of compounds 5}

To a magnetically stirred solution of carboxamide 3 (0.2 mmol, 1.0 equiv.) in $\mathrm{DMF}(2 \mathrm{~mL}), \mathrm{SOCl}_{2}$ (2.0 equiv) was added. Mixture was allowed to steer at $25^{\circ} \mathrm{C}$. Reaction was monitored by TLC, on $\mathrm{SiO}_{2}$ plates, using mixture of $n$-hexane/EtOAc $=6: 4$, as eluent. After $3 \mathrm{~h}$, mixture was concentrated by rotary evaporator to give a residue which was dissolved in $\mathrm{CH}_{2} \mathrm{Cl}_{2}$ and washed with brine $(2 \times 20 \mathrm{~mL})$. Organic layer was separated, and concentrated by rotary evaporator. Obtained crude product was purified by dry flash chromatography $\left(\mathrm{SiO}_{2} ; n\right.$-hexane/EtOAc $\left.=8: 2-2: 8\right)$.

\section{Procedure for the synthesis of compounds 6}

To a magnetically stirred solution of carbamate 4 (0.24 mmol, 1.0 equiv.) in dichloroethane ( $2 \mathrm{~mL})$, TMSI (3.5 equiv.) was added. Mixture was allowed to steer at $25^{\circ} \mathrm{C}$, in dark. Reaction was monitored by TLC, on $\mathrm{SiO}_{2}$ plates, using mixture of $\mathrm{CH}_{2} \mathrm{Cl}_{2} / \mathrm{MeOH}=9: 1$, as eluent. After $48 \mathrm{~h}$, excess of $\mathrm{MeOH}$ was added and the mixture was concentrated by rotary evaporator. $1 \mathrm{M}$ Solution of $\mathrm{HCl}$ was added to residue, and extracted with $3 \times 15 \mathrm{~mL} \mathrm{CH}_{2} \mathrm{Cl}_{2} .1 .5 \mathrm{M}$ $\mathrm{K}_{2} \mathrm{CO}_{3}$ was added to aqueous layer $(\mathrm{pH} \sim 11)$, and extracted with $3 \times 15 \mathrm{~mL}$ of $\mathrm{CH}_{2} \mathrm{Cl}_{2}$. Organic layers were combined and concentrated by rotary evaporator affording the crude product. There was no need for additional purification of the product.

\section{In vivo determination of antinociceptive activity}

The antinociceptive activity was determined by the tailimmersion [5] and the formalin test [12]. The experiments were approved by the Local Ethical Committee of the Faculty of Medicine, University of Belgrade (permit No. 5784/1) and the Ethical Council of the Ministry of Agriculture, Forestry and Water Management, which are in compliance with the European Community Council Directive of November 24th, 1986 (86/609/EEC) and the International Association for the Study of Pain (IASP) Guidelines for the Use of Animals in Research.

\section{Results and discussion}

\section{Chemistry}

As a part of our continuing research to develop new, more efficient opioid analgesics, we recently prepared compounds $\mathbf{2}, \mathbf{4}$ and $\mathbf{5}[10,11]$. Here, we report the significantly improved general synthetic procedure, as well as two novel derivatives, cis and trans 3-aminofentanyl 6. All the compounds were prepared and used as racemates only.

Synthesis of the compounds $\mathbf{2}$ and $\mathbf{4}$ involves the Hofmann rearrangement, in the presence of $\mathrm{N}$-bromoacetamide (NBA) and $\mathrm{LiOH} \cdot \mathrm{H}_{2} \mathrm{O}$ in $\mathrm{MeOH}[10,11]$. Although the relative stability of lithium $\mathrm{N}$-bromocarboxamide salts is known, the Hofmann rearrangement of NBA itself is base-promoted at elevated temperatures. Therefore, our original procedure involved reaction of the carboxamides at room temperature for $24-48 \mathrm{~h}$, requiring about 9 and 25 equiv. of $\mathrm{NBA}$ and $\mathrm{LiOH} \cdot \mathrm{H}_{2} \mathrm{O}$ respectively $[10,11]$. Subsequently, our microwave irradiation experiments revealed a dramatic rate acceleration, with the transformation being completed within few minutes at $65^{\circ} \mathrm{C}$. However, further tests showed that it was temperaturedependent only, with the simple heating having the same effect. Thus, the reaction proceeded some 300-600 times faster at $65{ }^{\circ} \mathrm{C}$ than at $20{ }^{\circ} \mathrm{C}$ (Scheme 1). This modified protocol afforded compounds cis-2,trans-2, cis-4 and trans-4 in 80-90\% yields, free of aryl brominated or other contaminants. Since NBA decomposition appeared insignificant, only half amount of the regents was sufficient,
101 


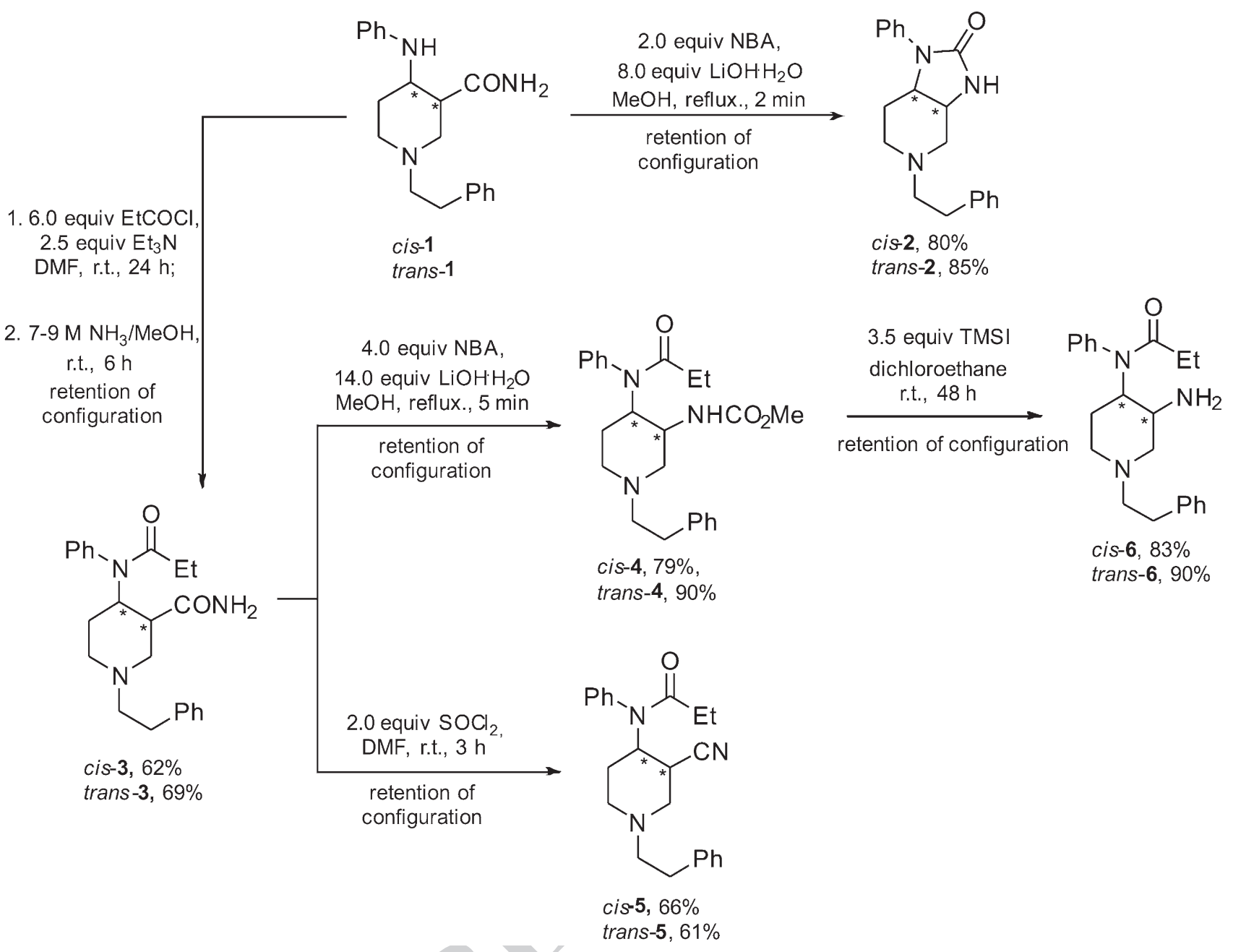

Scheme 1 Synthesis of fentanyl derivatives with nitrogen group at position $\mathrm{C}_{3}$

compared to the original procedure. The modification is applicable to a range of diverse aliphatic and aromatic carboxamides (not shown).

We also prepared nitriles 5 by dehydration of carboxamides 3 (Scheme 1). Initial dehydration with $\mathrm{SOCl}_{2}$ in toluene largely resulted in the recovered reactants. However, the reaction in DMF afforded moderate yields of cis-5 and trans-5 respectively, with the complete retention of configuration (Scheme 1).

Selective carbamate cleavage of cis-4 and trans-4 was achieved with trimethylsilyl iodide under mild reaction conditions, providing 3-amino fentanyl cis-6 and trans-6 in high yields, with the complete retention of configuration (Scheme 1). The reagent is particularly suitable, since it cleaves lower alkoxy groups quantitatively and selectively, while most other groups are tolerated. Also, it can be prepared inexpensively on a multi-gram scale.
In vivo antinociceptive activity of the 3-substituted fentanyl analogues 2-6

\section{Tail-immersion test}

Based on the determined $\mathrm{ED}_{50}$ values, the relative order of potency in tail-immersion test was found to be: fentanyl $(\mathbf{1})>$ cis-4 $(0.5700)>$ trans 3 -carbomethoxy fentanyl, denoted as $\mathbf{T},(0.0940)>$ cis $-\mathbf{5}(0.0092)=$ trans $-\mathbf{5}$ (0.0090) $>$ trans -4 (0.0032) (Table 1; Fig. 1a). Compounds cis-2, trans-2, cis-3, trans-3, cis-6 and trans-6 did not inhibit nociception in doses up to $2 \mathrm{mg} / \mathrm{kg}$ (Table 1). Saline injection in control rats had no effect on the tail-immersion latency (Fig. 1).

It has been previously demonstrated that antinociceptive potency of the 3-substituted fentanyl analogues is predominantly influenced by the steric factors (voluminosity of the

\begin{tabular}{|l|l|l|l|l|}
\hline Journal : Large 43440 & Article No : 121 & Pages : 7 & MS Code : 121 & Dispatch : 29-6-2020 \\
\hline
\end{tabular}


Table 1 Summary of MPE dose-response curves, relative potency and AUC-MPE curves for compounds tested

\begin{tabular}{|c|c|c|c|c|c|c|}
\hline Compound (mg/kg) & $\mathrm{ED}_{50}(\mathrm{mg} / \mathrm{kg})$ & $95 \% \mathrm{CL}$ & Dose-response slope \pm SEM & $r$ & Relative potency & $\begin{array}{l}\text { AUC-MPE } \\
\text { response } \\
\text { slope } \pm \text { SEM }\end{array}$ \\
\hline Fentanyl $(0.0636-0.0191) n=18$ & 0.0104 & $0.0050 \pm 0.0216$ & $114.96 \pm 14.60$ & 0.992 & 1 & $3.59 \pm 0.44$ \\
\hline $\begin{array}{l}\text { trans 3-Carbomethoxy fentanyl, } \\
\mathbf{T}(0.0445-0.267) n=18\end{array}$ & 0.1094 & $0.0856-0.1396$ & $69.42 \pm 1.80$ & 1 & $\begin{array}{l}0.0940 \\
0.0684-0.1282\end{array}$ & $2.32 \pm 0.09$ \\
\hline cis $-2 n=3$ & & & No activity in doses up to $2 \mathrm{mg} / \mathrm{kg}$ & & & \\
\hline trans $-2 n=3$ & & & No activity in doses up to $2 \mathrm{mg} / \mathrm{kg}$ & & & \\
\hline$c i s-3 n=3$ & & & No activity in doses up to $2 \mathrm{mg} / \mathrm{kg}$ & & & \\
\hline trans $-3 n=3$ & & & No activity in doses up to $2 \mathrm{mg} / \mathrm{kg}$ & & & \\
\hline cis-4 (0.092-0.0276) $n=18$ & 0.0182 & $0.0132-0.0250$ & $91.72 \pm 5.01$ & 0.999 & $\begin{array}{l}0.5700 \\
0.4424-0.7242\end{array}$ & $0.65 \pm 0.14^{\mathrm{a}}$ \\
\hline trans-4 (1.84-3.68) $n=18$ & 3.2382 & $1.6316-6.4268$ & $103.72 \pm 16.12$ & 0.988 & $\begin{array}{l}0.0032 \\
0.0025-0.0041\end{array}$ & $1.95 \pm 0.08$ \\
\hline cis-5 $(0.9-1.8) n=18$ & 1.1268 & $0.8173 \pm 1.5536$ & $122.79 \pm 10.32$ & 00 & $\begin{array}{l}0.0092 \\
0.0076-0.0113\end{array}$ & $1.55 \pm 0.12$ \\
\hline trans $-5(0.9-1.8) n=18$ & 1.1634 & $0.5433 \pm 2.4913$ & $147.76 \pm 30.29$ & & $\begin{array}{l}0.0090 \\
0.0067-0.0123\end{array}$ & $1.49 \pm 0.21$ \\
\hline cis- $6 n=3$ & & & No activity in doses up to $2 \mathrm{mg} / \mathrm{kg}$ & & & \\
\hline trans- $6 n=3$ & & & No activity in doses up to $2 \mathrm{mg} / \mathrm{kg}$ & & & \\
\hline
\end{tabular}

Results are summarized from data presented in Fig. $1 . \mathrm{ED}_{5 \mathrm{O}} \mathrm{s}$ were calculated from three doses of each compound with 6-8 rats per dose $n$ total number of animals employed to produce the respective dose-response curve, $C L$ confidence limits, $r$ correlation coefficient, $M P E$ maximum possible antinociceptive effect, $A U C-M P E$ area under the curve-maximum possible antinociceptive effect

${ }^{a}$ Significantly $(p<0.05)$ different in comparison with trans 3-carbomethoxy fentanyl. All computations were done according to Tallarida and Murray [13]

groups and cis/trans isomerism) [5, 14, 15]. For example, cis-3-methyl fentanyl and cis-3-ethyl fentanyl are about 8 and 1.5 times more potent than fentanyl, respectively. However, trans isomers of 3-methyl and 3-ethyl fentanyl are about 2 times more potent and equipotent to fentanyl, respectively. More voluminous alkyl groups cause a gradual drop in the activity compared to fentanyl itself $[5,8,15,16]$. In this research, we determined that cis- $\mathbf{4} /$ trans $\mathbf{- 4}$ potency ratio was 180 . Also, very significantly, we found that the chemical nature of substituents critically influenced the potency. Thus, while compound $\mathbf{4}$ (with methyl carbamate substituent) is very active, compounds $\mathbf{3}$ and $\mathbf{6}$ (having carbamoyl and amino groups respectively), lack significant antinociceptive activity in doses up to $2 \mathrm{mg} / \mathrm{kg}$. Also, 3-cyano fentanyl 5 has a very low potency compared to fentanyl, Table 1 .

The antinociceptive effect of fentanyl peaked at about 15-20 min, while the equianalgesic doses of cis-4, trans-4, cis-5, trans-5 and $\mathbf{T}$ peaked at about 5-10 min (Fig. 2).

Previously we have shown that 3-carbomethoxy fentanyl has a shorter duration of action than fentanyl and its duration of action is not affected by cis/trans isomerism [5]. It was assumed that the time course of action of 3-carbomethoxy fentanyl is influenced by the nature of the carbomethoxy group. In this study, cis-4, trans-4, cis-5 and trans-5 also showed shorter duration of action (Fig. 1) than fentanyl, as indicated by lower AUC-MPE response slopes (Fig. 2b;
Table 1). These differences were not statistically significant $(p>0.05)$. However, the duration of action of $c i s-4$ was statistically $(p<0.05)$ shorter than that of $( \pm)$ trans 3 -carbomethoxy fentanyl (T) (Fig. 2b; Table 1).

The antinociceptive activity of $4 \mathrm{ED}_{50}$ of each of the compound tested was abolished by subcutaneous naloxone hydrochloride $(0.1 \mathrm{mg} / \mathrm{kg}$; s.c; Fig. 1$)$ indicating that the effect is mediated via opioid receptors.

\section{Formalin test}

Injection of formalin into the hind paw results in a biphasic pain behavior; the first phase results from direct effect of formalin on nociceptors, whereas the second phase represents tissue injury. Thus, more central pain processing mechanisms are involved in the establishment of chronic neuropathic or inflammatory pain $[17,18]$.

In the present study we compared fentanyl and cis-4 in two different types of nociceptive tests: tonic (formalin-induced inflammation) and phasic (tail-immersion). Our results indicate that fentanyl and cis-4 are effective antinociceptive agents in the both tests and their effects are dose-dependent (Fig. 2a, c). We found that fentanyl is about 10 times less potent in formalin test then in tailimmersion test $\left(\mathrm{ED}_{50}=0.1021\right.$ vs $\left.\mathrm{ED}_{50}=0.0104\right)$, in close agreement with one literature report [19]. However,

\begin{tabular}{|l|l|l|l|l|}
\hline Journal : Large 43440 & Article No : 121 & Pages : 7 & MS Code : 121 & Dispatch : 29-6-2020 \\
\hline
\end{tabular}



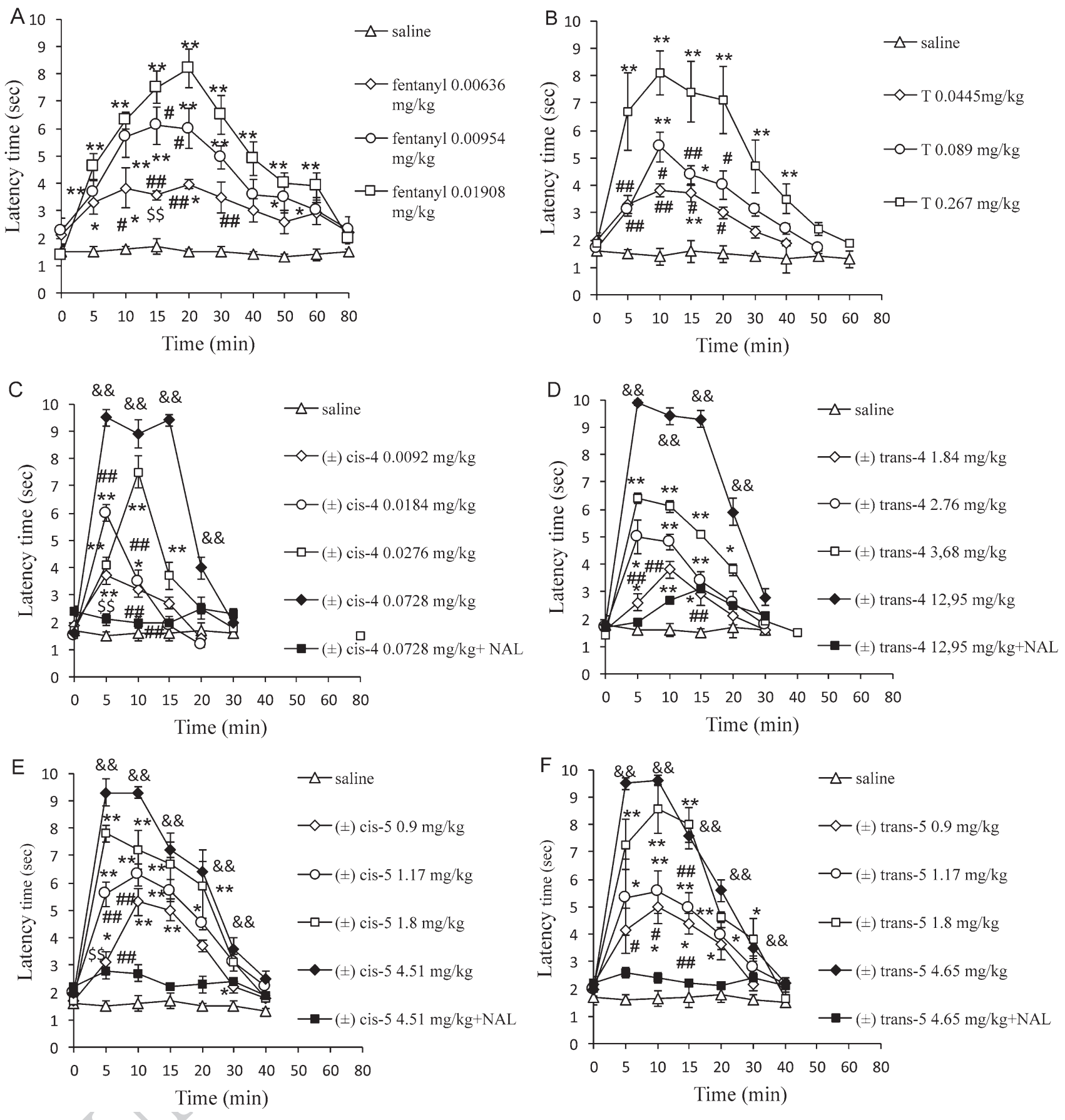

Fig. 1 The time-response curves on the tail-immersion for fentanyl (a), trans 3-carbomethoxy fentanyl (b), cis-4 (c), trans-4 (d), cis-5 (e), and trans-5 (f) given i.p. in rats and the antagonism with naloxone. Each point represents the mean \pm SEM of the antinociception in six to eight rats. At each time interval the differences between the corresponding means were verified using the one-way analysis of variance (ANOVA), followed by Tukey's HSD post hoc test where statistical significance was determined by comparing with the control $(0.9 \% \mathrm{NaCl})(* p<0.05, * * p<0.01)$, a comparing with the fentanyl $0.01908 \mathrm{mg} / \mathrm{kg}\left({ }^{\#} p<0.05,{ }^{\# \#} p<0.01\right)$, b comparing with trans 3 -carbomethoxy fentanyl $0.267 \mathrm{mg} / \mathrm{kg}\left({ }^{\#} p<0.05,{ }^{\# \#} p<0.01\right)$, c comparing with the cis-4 $0.0276 \mathrm{mg} / \mathrm{kg}\left({ }^{\#} p<0.05,{ }^{\# \#} p<0.01\right)$; cis-4 $0.0184 \mathrm{mg} /$

$\mathrm{kg}\left({ }^{\$} p<0.05,{ }^{\$} p<0.01\right) ; \mathbf{d}$ comparing with the tans-4 $3.68 \mathrm{mg} /$ $\mathrm{kg}\left({ }^{\#} p<0.05,{ }^{\#} p<0.01\right)$, e comparing with the cis-5 $1.8 \mathrm{mg} / \mathrm{kg}$ $\left({ }^{\#}<0.05, \# p<0.01\right) ; c i s-51.17 \mathrm{mg} / \mathrm{kg}\left({ }^{\$} p<0.05,{ }^{\$}{ }^{\$} p<0.01\right)$, f comparing with the trans $-51.8 \mathrm{mg} / \mathrm{kg}\left({ }^{\#} p<0.05,{ }^{\# \#} p<0.01\right)$. c-f The differences between $4 \mathrm{ED}_{50}$ and $4 \mathrm{ED}_{50}+$ naloxone was verified using the $t$ test for unpaired values $\left({ }^{\&} p<0.05,{ }^{\&} \& p<0.01\right)$. The mean \pm SEM of latencies before and $10 \mathrm{~min}$ after saline injection were found to be: $1.6 \pm 0.1$ and $1.5 \pm 0.3 \mathrm{~s}$, respectively ( $p<0.0, t$ test for paired values; a), $1.6 \pm 0.1$ and $1.5 \pm 0.2 \mathrm{~s}$, respectively $(p<0.05 ; \mathbf{b}), 1.7 \pm 0.2$ and $1.6 \pm 0.3 \mathrm{~s}$, respectively $(p<0.05 ; \mathrm{c}), 1.8 \pm 0.3$ and $1.6 \pm 0.3 \mathrm{~s}$, respectively $(p<0.05 ; \mathbf{d}), 1.6 \pm 0.2$ and $1.6 \pm 0.3 \mathrm{~s}$, respectively $(p<0.05 ; \mathbf{e})$ and $1.7 \pm 0.3$ and $1.7 \pm 0.3 \mathrm{~s}$, respectively $(p<0.05 ; \mathbf{f})$

\begin{tabular}{|l|l|l|l|l|}
\hline Journal : Large 43440 & Article No : 121 & Pages : 7 & MS Code : 121 & Dispatch : 29-6-2020 \\
\hline
\end{tabular}


A

B
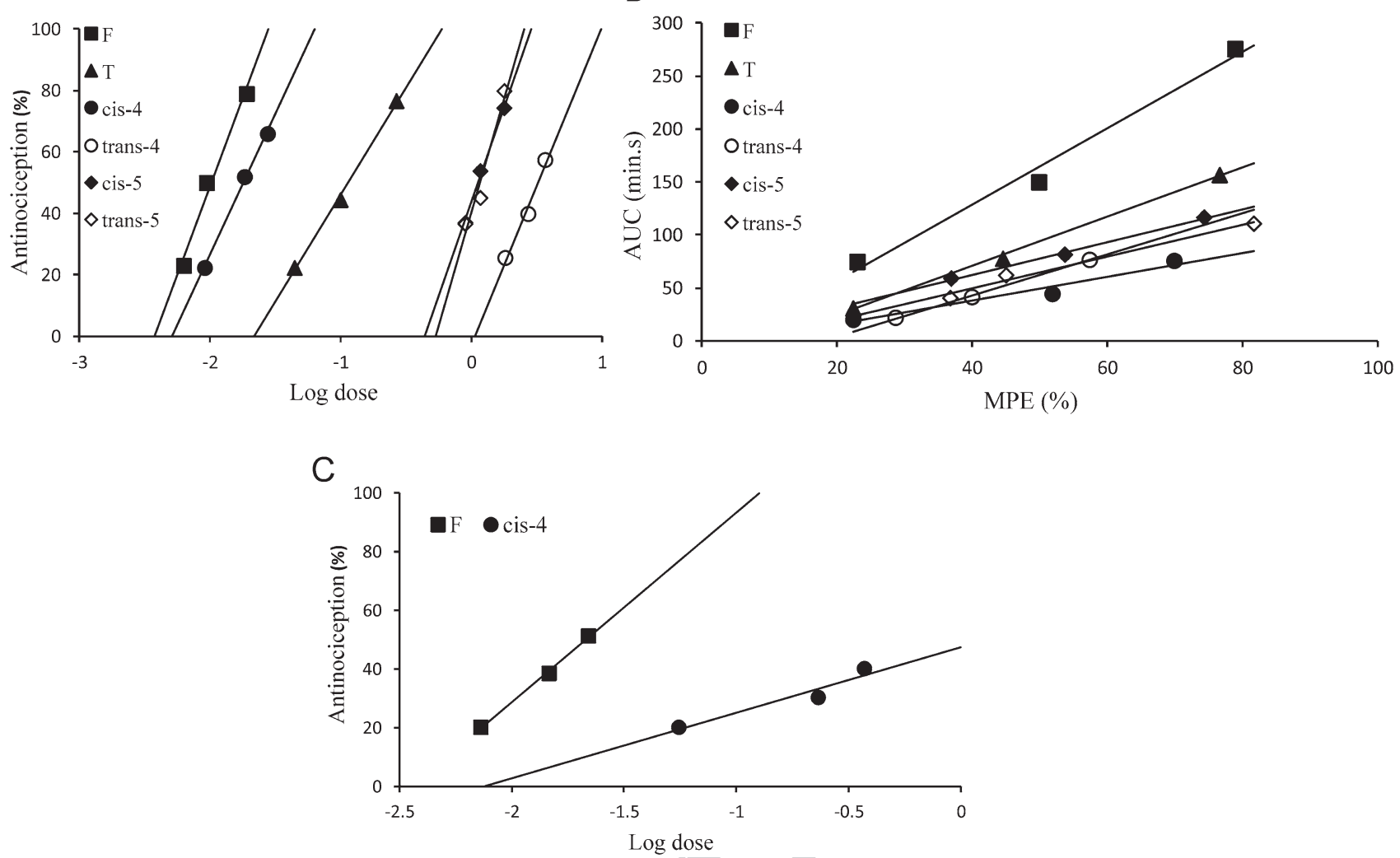

Fig. 2 The log dose-response curves (a) and AUC-MPE curves (b) on the tail-immersion for compounds tested; the log dose-response curves on the formalin test for compounds tested (c). Each point represents the mean \pm SEM of the antinociception in six to eight rats.
Dose-response slopes \pm SEM for fentanyl and cis-4 are $64.62 \pm 2.9$ and $22.57 \pm 6.5$, respectively. Correlation coefficients $(r)$ for fentanyl and cis-4 are 0.99 and 0.96 , respectively

\section{Conclusions}

The optimized synthetic route towards fentanyl analogs bearing nitrogen groups in position $\mathrm{C}_{3}$ of piperidine ring is presented herein. Ten compounds were tested in vivo for their antinociceptive activity. Compound cis-4 showed pharmacological behavior similar to fentanyl. It is characterized by high potency, rapid onset and short duration of action. Therefore, it has potential to be incorporated in different pharmaceutical forms. Further studies should evaluate tolerability and safety of this series of novel fentanyl analogs and compare them to fentanyl [3].

Acknowledgements This work was financially supported by the Ministry of Education, Science and Technological Development of the Republic of Serbia (Grant nos. 451-03-68/2020-14/200026 and 451-03-68/2020-14/200110).

\begin{tabular}{|l|l|l|l|l|}
\hline Journal : Large 43440 & Article No : 121 & Pages : 7 & MS Code : 121 & Dispatch : 29-6-2020 \\
\hline
\end{tabular}




\section{Compliance with ethical standards}

Conflict of interest Authors declare that there are no conflicts of interest.

\section{References}

1. Manglik A, Lin H, Aryal DK, McCorvy JD, Dengler D, Corder G, Levit A, Kling RC, Bernat V, Hübner H, Huang X-P, Sassano MF, Giguère PM, Löber S, Duan D, Scherrer G, Kobilka BK, Gmeiner P, Roth BL, Shoichet BK. Structure-based discovery of opioid analgesics with reduced side effects. Nature. 2016;537:185-90.

2. Matthes HW, Maldonado R, Simonin F, Valverde O, Slowe S, Kitchen I, Befort K, Dierich A, Le Meur M, Dollé P, Tzavara E, Hanoune J, Roques BP, Kieffer BL. Loss of morphine-induced analgesia, reward effect and withdrawal symptoms in mice lacking the $\mu$-opioid-receptor gene. Nature. 1996;383:819-23.

3. Vučković S, Savić-Vujović K, Ivanović M, Došen-Mićović LJ, Todorović Z, Vučetić Č, Prostran M, Prostran M. Neurotoxicity evaluation of fentanyl analogs in rats. Acta Vet. 2012;62:3-15.

4. Janssen PA, Niemegeers CJ, Dony JG. The inhibitory effect of fentanyl and other morphine-like analgesics on the warm water induced tail withdrawal reflex in rats. Arzneimittelforschung. 1963;13:502-7.

5. Vučković S, Prostran M, Ivanović M, Ristović Z, Stojanović R. Antinociceptive activity of the novel fentanyl analogue iso-carfentanil in rats. Jpn J Pharmacol. 2000;84:88-195.

6. Ivanović MD, Mićović IV, Vučković S, Prostran M, Todorovic Z, Kiricojevic VD, Djordjevic JB, Dosen-Micovic LJ. The synthesis and preliminary pharmacological evaluation of racemic cis and trans 3-alkylfentanyl analogues. J Serb Chem Soc. 2004;69:511-26.

7. Wang DD, Ma TT, Zhu HD, Peng CB. Transdermal fentanyl for cancer pain: trial sequential analysis of 3406 patients from 35 randomized controlled trials. J Cancer Res Ther. 2018;14:S14-S21.

8. Vučković S, Prostran M, Ivanović M, Došen-Mićović LJ, Todorović Z, Nešić Z, Stojanović R, Divac N, Miković Z. Fentanyl analogs: structure-activity-relationship study. Curr Med Chem. 2009;16:2468-74.

9. Vardanyan RS, Hruby VJ. Fentanyl-related compounds and derivatives: current status and future prospects for pharmaceutical applications. Future Med Chem. 2014;6:385-412.
10. Jevtić II, Došen-Mićović LJ, Ivanović ER, Todorović NM, Ivanović MD. Synthesis of orthogonally protected ( \pm )-3-amino4-anilidopiperidines and ( \pm )-3- $N$-carbomethoxyfentanyl. Synthesis. 2017;49:3126-36.

11. Jevtić II, Došen-Mićović LJ, Ivanović E, Ivanović MD. Hofmann rearrangement of carboxamides mediated by $\mathrm{N}$-bromoacetamide. Synthesis. 2016;48:1550-60.

12. Vujović KS, Vučković S, Vasović D, Medić B, Knežević N, Prostran M. Additive and antagonistic antinociceptive interactions between magnesium sulfate and ketamine in the rat formalin test. Acta Neurobiol Exp (Wars). 2017;77:137-46.

13. Tallarida RJ, Murray RB. The manual of pharmacologic calculations with computer programs. 2nd ed. New York: Springer; 1986.

14. Van Bever WF, Niemegeers CJ, Schellekens KH, Janssen PA. $N$-4-Substituted 1-(2-arylethyl)-4-piperindyl- $N$-phenylpropanamides, a novel series of extremely potent analgesics with unusually high safety margin. Arzneimittelforschung. 1976;26:1548-51.

15. Casy AF, Parfitt RT. The opioid analgesics, chemistry and receptors. New York: Plenum Press; 1986.

16. Casy AF, Ogungbamila FO. 3-Allyl analogues of fentanyl. J Pharm Pharmacol. 1982;34:210.

17. Pitcher GM, Henry JL. Governing role of primary afferent drive in increased excitation of spinal nociceptive neurons in a model of sciatic neuropathy. Eur J Neurosci. 2002;15:1509-15.

18. Vissers K, Hoffmann V, Geenen F, Biermans R, Meert T. Is the second phase of the formalin test useful to predict activity in chronic constriction injury models? A pharmacological comparison in different species. Pain Pract. 2003;3:298-309.

19. Meert TF, Vermeirsch HA. A preclinical comparison between different opioids: antinociceptive versus adverse effects. Pharmacol Biochem Behav. 2005;80:309-26.

20. McLaughlin CR, Dewey WL. A comparison of the antinociceptive effects of opioid agonists in neonatal and adult rats in phasic and tonic nociceptive tests. Pharmacol Biochem Behav. 1994;49:1017-23.

21. Ahn JS, Lin J, Ogawa S, Yuan C, O’Brien T, Le BH, Bothwell A, Moon MH, Hadjiat Y, Ganapathi A. Transdermal buprenorphine and fentanyl patches in cancer pain: a network systematic review. J Pain Res. 2017;10:1963-72.

Publisher's Note Springer Nature remains neutral with regard to jurisdictional claims in published maps and institutional affiliations. 